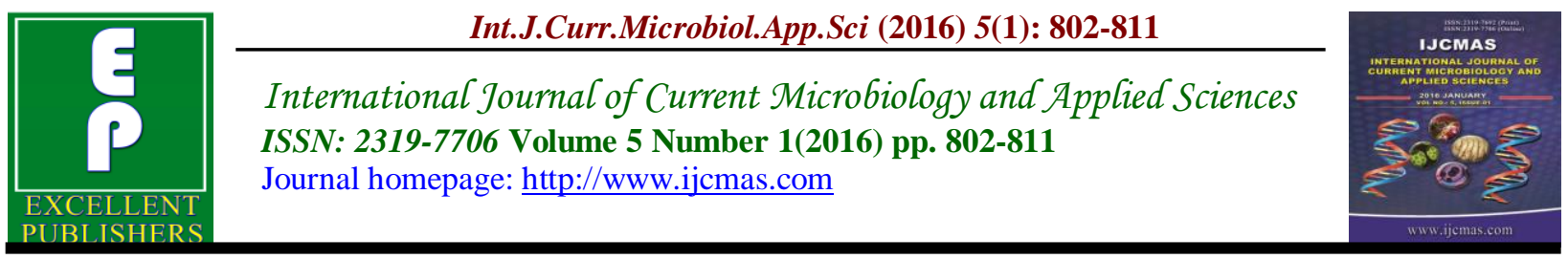

Original Research Article

http://dx.doi.org/10.20546/ijcmas.2016.501.082

\title{
Chemical, Microbiological and Sensory Evaluation of Probiotics Beverages Prepared with Permeate and Rosella
}

\author{
Amany R. El- Baily* \\ Food Technology Research Institute, Agric. Res. Center, Giza, Egypt \\ *Corresponding author
}

\begin{abstract}
A B S T R A C T
Keywords

Evaluation,

Probiotics

Beverages,

Permeate,

Rosella

Article Info

Accepted:

06 December 2015

Available Online:

10, January 2016

Probiotics have several advantages for human health. While looking for alternative food matrices, Chemical, microbiological and sensory evaluation of probiotics beverages prepared with different ratios of permeate and rosella were evaluated at zero time and during storage periods at 7,14 and 21 days in refrigerator at $4 \pm 1^{\circ} \mathrm{C}$. Results indicated that the increase gradually of acidity and decreased of $\mathrm{pH}$ values by increasing rosella percentage. During storage periods the $\mathrm{pH}$ values were decreased gradually and increasing gradually in acidity in all treatments throughout storage period of 21 days. The results revealed to gradually decrease in total polyphenols and flavonoids contents at 7, 14 and 21 days, respectively. The highly decrease in total polyphenols and flavonoids contents were shown in formula 2 prepared with $2.0 \%$ rosella. In contrast, anthocyanin was highly decreased in formula 4 (6\% rosella). Also, negligible decrease was noticed in tannins, $\mathrm{Zn}$ and Fe contents during refrigeration storage. These results due to bifidobacteria used polyphenols, flavonoidsto stable of bifidobacteria count during storage, while bifidobacteria left saponins, tannins, $\mathrm{Zn}$ and Fe without use. Slightly decrease the number of bifidobacteria during storage, but the minimum allowable is due to the use of antioxidants that limit the deterioration of a number of beneficial bacteria. The rosella permeate beverages prepared with $4.0 \%$ rosella (formula 3 ) gained the highest score for color, appearance and flavor at zero time of storage and after 21 days of storage at $4^{\circ} \mathrm{C} \pm 1^{\circ} \mathrm{C}$.
\end{abstract}

\section{Introduction}

Permeate is an important by-product of the treat of milk by using ultra filtration process in cheese industry. Permeate contains lactose as the major constituent in addition to water soluble vitamins and the salts of milk. Therefore, permeate can be considered as a solution of nutritious significance. Permeate retains about $80 \%$ of the initial lactose of the treated milk. The milk permeate is practically free of $\mathrm{N}$-compounds and thus unsuitable for animal feeding
(Marhamatizadeh et al., 2012). Therefore, permeate can be considered as a solution of nutritious significance. In this respect, Renner and Abd El-Salam (1991) reported that permeate appears as a crystal clear, greenish fluid. Besides lactose, minerals and vitamins are fractioned between the retentate and permeate. This is quite important since permeate itself has to produce an electrolyte beverage and different drinks respectively or carrying out fermentation using yogurt culture or different starters (Abd El-Salam et 
al., 1991) or LAB containing Lactobacillus helveticus, LH100 (Abd El-Khair, 2009) to produce fruit beverages and sports drink respectively. Bifidobacteria are one of the most important probiotics in dairy products (Parvez et al., 2006; Russell et al., 2011). Probiotics are live microorganisms which when administered in adequate amounts confer a health benefit on the host (Oliveira et al., 2011). Bifidobacteria have positive effects on human health: (1) synthesis of vitamins (Crittenden et al., 2003; Beitane and Ciprovica, 2011);

immunostimulation (Dong et al., 2010); (3) cholesterol reduction (Ziarno et al., 2007; Beitane, 2008); (4) lactose hydrolysis (He et al., 2007); and (5) prevention of infectious diarrhea (Qiao et al., 2002). Nutritional benefits of bifidobacteria are genetically determined. Bifidobacteria are saccharolytic and produce organic acids (Russell et al., 2011). The growth of bifidobacteria can be promoted with addition of prebiotics (Rastall and Maitin, 2002). Some of the important health benefits attributed for Bifidobacterium spp. are control of undesirable microorganisms in intestinal tract, reduction in serum cholesterol levels (Hughes \& Hoover, 1991).

Roselle (Hibiscus sabdariffa L.) is a tropical plant which belongs to the family Malvaceae and is in Egypt as Karkadah. It is probably a native of West Africa and is now widely cultivated throughout the tropics and subtropics e. g. Sudan, China, Thailand, Egypt, Mexico, and the West India (El-Saidy et al., 1992). In addition, Roselle juice, which is conventionally made from water extraction of fresh or dried Roselle calyxes, has been reported as being a popular soft drink with daily consumption in many countries including Egypt, Sudan, Mexico, Nigeria and Thailand (Aurelio et al., 2007). The chemical components contained in the flowers of Hibiscus sabdariffa include anthocyanins, flavonoids and polyphenols (Tzu-Li Lin et al.,2007). The petals are potentially a good source of antioxidant agents as anthocyanins and ascorbic acid (Prenesti et al., 2007). Roselle calyx contains a rich source of dietary fiber, vitamins, minerals and bioactive compounds such as organic acids, phytosterols, and polyphenols, some of them with antioxidant properties.(Aurelio et al., 2007). Recently, the biological activities of anthocyanins, such as antioxidant activity and anticarcinogenic activity have been investigated (Tsai et al., 2002). The rosella calyces are rich in anthocyanin, ascorbic acid and hibiscus acid. It is water soluble with brilliant and attractive red color and with sour and agreeable acidic taste which aid digestion (Asolkar et al., 1992).

Studies dealing with the production of fermented rosella extracts used B. bifidum bacteria. In this study, the changes of microbial population and some major components in rosella extracts during fermentation with bifidobacteria were investigated. The aim of this is to determine the suitability of rosella extracts as a raw material for the production of UF- permeates based probiotic beverages.

\section{Materials and Methods}

\section{Materials}

Milk permeates was obtained from SoradGarbyia Industrial region, Egypt. It was a by-product from the cow's milk. It was prepared at $50^{\circ} \mathrm{C}$ using spiral-wound module membrane. The permeate was immediately heated in a water bath at $85^{\circ} \mathrm{C}$ for $15 \mathrm{~min}$., and then cooled to $4 \pm 1^{\circ} \mathrm{C}$.

Roselle Calyces (Hibiscus sabdariffa L.) were used as source of the natural pigments investigated in the present study. The dried 
calyces of Roselle were purchased from a local market in Cairo, Egypt.

The dried Roselle calyces were ground for 3 second using a blender (Braun KMM 30 mill), (Germany). The dried calyces were immediately packed in polyethylene bags and kept at low temperature $\left(4^{\circ} \mathrm{C}\right)$ till used.

Bifidobacteria strain (Bifidibacterium befidum, Bb.12) was obtained from chr. Hansen, Denmark.

\section{Preparation of Different Formulas}

It was prepared by blending cold permeate with $2 \%, 4 \%$ or $6 \%$ powder rosella calyxes $(\mathrm{w} / \mathrm{v})$ and dipping overnight, then the mixing was filtered. After that, sucrose $4 \%$ was added to filtrates then pasteurized to $72^{\circ} \mathrm{Cat} 15 \mathrm{~min}$. After pasteurization, the mixtures were cooled at $38^{\circ} \mathrm{C}$, and then bifidobacteria (Bifidibacterium befidum) were added $1 \%\left(10^{8} \mathrm{cfu} / \mathrm{g}\right)$ to mixtures and incubated at $38^{\circ} \mathrm{C} / 3 \mathrm{~h}$. The final mixtures were filled into the sterilized bottles and stored at $4^{\circ} \mathrm{C}$ for 21 days. This experiment was carried out in triplicate and all analysis was carried out in triplicate.

Formula (1) permeate+ bifidobacteria,

Formula (2) permeate+ bifidobacteria $+2 \%$ rosella

Formula (3) permeate+ bifidobacteria $+4 \%$ rosella,

Formula (4) permeate+ bifidobacteria $+6 \%$ rosella.

\section{Analytical Methods}

$\mathrm{pH}$ value was measured using a $\mathrm{pH}$ meter as described by Ling (1963). Soluble nitrogen (S.N) and titratable acidity was determined by Ling (1963). Total solids were determined using oven drier according to AOAC (2000). Ash, protein and fat contents were determined as reported in AOAC
(2000). Lactose was determined in UFpermeate by HPLC (Hewlett Packrd 1040A) detection as given by (Jeon et al., 1984).

Folin-Ciocalteu reagent was used to determine total polyphenols in formulas (Singleton and Rossi, 1965). The content of flavonoids was determined by a Pharmacopeia method (1989). Saponins were determined by the method of Hiai et al. (1976). Total anthocyanins content of Roselle extract was determined calorimetrically according to the procedure described by Du and Francis (1973). Whereas, total tannins (as tannic acid) as described by AOAC (2000).

Minerals content were determined after ash using Atomic Absorption Spectrophotometer, Perkin-Elmer 3300 (USA) according to Raganna (1979)

\section{Microbiological analysis}

Bifidobacterium bifidum (Bb12) counts were determined according to Dave and Shah (1996) using modified MRS agar supplemented with $0.05 \%$ L-cysteine and $0.3 \%$ lithium chloride. The plates were anaerobically incubated at $37^{\circ} \mathrm{C}$ for $48 \mathrm{hrs}$. Molds \&Yeasts were determined according to Standard Methods for Examination of Dairy products (APHA, 1994). Coliforms were determined according to Harrigan and McCance (1996).Spore forms were determined according to Marshall (1993).

\section{Sensory evaluation}

Sensory evaluation of the prepared formulas was carried out to fresh and during storage at 21 days by panel tests of 10 judges. The maximum attainable scoring point 10, 10 and 10 points for Color, Taste, Flavour and Overall acceptability (Fasoyiro, et al., 2005). 


\section{Statistical Analysis}

SPSS for version 17.0 (2011) computer programs was used for statistical analysis. The probability $\mathrm{p}<0.05$ was considered as significant.

\section{Results and Discussion}

Chemical composition of dried Roselle calyxes and permeate are presented in Table (1). It could be noticed that dried Roselle calyxes contains 89.20 total solid 12.89 ash, 0.43 fat and $8.22 \%$ protein, while UFpermeate contained 5.69 total solid , 0.54 ash, 0.21 protein and $4.42 \%$ lactose. On the other hand, calcium, iron and zinc were 604.66, 33.05 and $5.61 \mathrm{mg} / 100 \mathrm{~g}$ in dried Roselle calyxes and 40.71, 0.073 and 0.03 $\mathrm{mg} / 100 \mathrm{~g}$ in permeate, respectively. The permeate contained the highest content of potassium $48.63 \mathrm{mg} / 100 \mathrm{~g}$. These results are in agreement with (Adenipeku, 1998) that showed that the rosella calyces contain $11.33 \%$ moisture and $6.90 \%$ protein. The results indicate the nutritional content of calyces compared well literature value. Typical literature values are; carbohydrates $(68.75 \%)$, protein $(6.71 \%)$ and fat $1.01 \%)$. This may be attributable to the source of calyces (Ameh et al., 2009)

The effect of added rosella calyxes on $\mathrm{pH}$ values and titratable acidity of different formula during storage periods at $4{ }^{\circ} \mathrm{C}$ are illustrated in Table (2). Total acidity was increased gradually by increasing rosella percentage compared to formula 1 (control). While, the $\mathrm{pH}$ value ranged from 6.10 to 5.40 in formula contained gradient rosella percentage. Results indicated that the increase gradually of acidity and decreased of $\mathrm{pH}$ values by increasing rosella calyxes percentage. During storage periods the $\mathrm{pH}$ values were decreased gradually and increasing gradually in acidity in all treatments throughout storage period of 21 days. The reason for increase in acidity and decrease in $\mathrm{pH}$ is due to conversion of lactose to lactic acid during storage period (Nuzhat et al., 2003).

Total polyphenols and flavonoids contents in permeate beverages prepared with adding $2.0,4.0$ and $6.0 \%$ dried roselle calyxes during cold storage periods after 21 days at $\left(4 \pm 1^{\circ} \mathrm{C}\right)$ are presented in Table (3). Data indicated to gradually decrease in total polyphenols and flavonoids contents at 7, 14 and 21 days, respectively.

The highly decrease in total polyphenols and flavonoids contents was found in formula 2 which contained $2 \%$ rosella. The microbial (e.g. Bifidobacterium sp.) in colon is hydrolyze non-absorbed polyphenols which can further be metabolized to aromatic acids like phenyl acetic, phenyl propionic, phenyl valeric and benzoic acids (Manach et al., 2004, Kroon et al., 2004 and Bosscher et al., 2009), which explain the cause of lowering level of polyphenols and flavonoids content.

Total anthocyanin and tannin contents in permeate beverages prepared with adding $2.0,4.0$ and $6.0 \%$ dried rosella calyxes during cold storage periodafter21 days at $\left(4 \pm 1^{\circ} \mathrm{C}\right)$ are illustrated in Table (4). Data indicated slightly decrease in anthocyanin and negligible decrease in tannins contents during refrigerator storage. In parallel, no change of $\mathrm{Zn}$ and $\mathrm{Fe}$ contents were noticed within storage Table (5). These results are due to the use of bifidobacteria to polyphenols, flavonoids, to stable of bifidobacteria count during storage, while bifidobacteria left anthocyanin, tannins, $\mathrm{Zn}$ and Fe without using. 
Table.1 Chemical Properties of Rosella calyxes and Permeate (\%)

\begin{tabular}{|c|c|c|}
\hline Items & Dry rosella calyxes & Fresh Permeate \\
\hline Total solid & $\mathbf{8 9 . 2 0}$ & $\mathbf{5 . 6 9}$ \\
\hline Fat & $\mathbf{0 . 4 3}$ & -- \\
\hline Protein & 8.22 & -- \\
\hline Soluble nitrogen & ND & $\mathbf{0 . 4 3}$ \\
\hline Ash & $\mathbf{1 2 . 8 9}$ & $\mathbf{0 . 6 1}$ \\
\hline Lactose & ND & $\mathbf{4 . 4 2}$ \\
\hline Potassium $\mathbf{m g} / \mathbf{1 0 0 g}$ & $\mathbf{2 2 . 9 8}$ & $\mathbf{4 8 . 6 3}$ \\
\hline Iron $\mathbf{m g} / \mathbf{1 0 0 g}$ & $\mathbf{3 3 . 0 5}$ & $\mathbf{0 . 0 7}$ \\
\hline Zinc $\mathbf{m g} / \mathbf{1 0 0 g}$ & $\mathbf{5 . 6 1}$ & $\mathbf{0 . 0 3}$ \\
\hline Calcium $\mathbf{m g} / \mathbf{1 0 0 g}$ & $\mathbf{6 0 4 . 6 6}$ & $\mathbf{4 0 . 7 1}$ \\
\hline
\end{tabular}

Table.2 Change on Acidity\% and pH Values for Formulas during Cold Storage Periods after 21 days at $\left(4 \pm 1^{\circ} \mathrm{C}\right)$

\begin{tabular}{|c|c|c|c|c|c|c|c|c|}
\hline \multirow[t]{2}{*}{ Treatments } & \multicolumn{4}{|c|}{ Acidity \% } & \multicolumn{4}{|c|}{ pH Values } \\
\hline & 0 time & 7 days & 14days & 21 days & 0 time & 7 days & 14 days & 21 days \\
\hline Formula 1 & $0.16^{d}$ & $0.20^{c}$ & $0.24^{\mathrm{d}}$ & $0.27^{d}$ & $6.65^{\mathrm{a}}$ & $6.51^{a}$ & $6.30^{\mathrm{a}}$ & $5.91^{a}$ \\
\hline Formula 2 & $0.20^{\mathrm{c}}$ & $0.22^{b c}$ & $0.27^{\mathrm{c}}$ & $0.30^{\mathrm{c}}$ & $6.41^{b}$ & $6.10^{b}$ & $6.06^{b}$ & $5.80^{b}$ \\
\hline Formula 3 & $0.25^{b}$ & $0.28^{b}$ & $0.31^{b}$ & $0.39^{b}$ & $5.80^{\mathrm{c}}$ & $5.60^{c}$ & $5.15^{\mathrm{c}}$ & $4.90^{c}$ \\
\hline Formula 4 & $0.29^{\mathrm{a}}$ & $0.32^{\mathrm{a}}$ & $0.37^{\mathrm{a}}$ & $0.39^{\mathrm{a}}$ & $5.84^{d}$ & $5.30^{d}$ & $5.15^{d}$ & $4.88^{\text {cd }}$ \\
\hline
\end{tabular}

Values with different letters in the same column are significant different at $P<.0 .05$

Formula (1) permeate+ bifidobacteria $\quad$ Formula (2) permeate+ bifidobacteria $+2 \%$ rosella

Formula (3) permeate + bifidobacteria $+4 \%$ rosella $\quad$ Formula (4) permeate+ bifidobacteria $+6 \%$ rosella

Table.3 Total Polyphenols and Flavonoids Contents $(\mathrm{Mg} / 100 \mathrm{ml})$ in Different Formulas During Cold Storage Periods after 21 Days at $\left(4 \pm 1^{\circ} \mathrm{C}\right)$

\begin{tabular}{|c|c|c|c|c|c|c|c|c|}
\hline \multirow[t]{2}{*}{ Treatments } & \multicolumn{4}{|c|}{ Total Polyphenols } & \multicolumn{4}{|c|}{ Flavonoids } \\
\hline & Otime & 7 days & 14 days & 21 days & 0 time & 7 days & 14 days & 21days \\
\hline $\begin{array}{l}\text { Rosella } \\
\text { calyxes }\end{array}$ & \multicolumn{4}{|c|}{ 49.20mg/g dry weight } & \multicolumn{4}{|c|}{$30.40 \mathrm{mg} / \mathrm{g}$ dry weight } \\
\hline Formula 1 & $2.80^{d}$ & $2.30^{d}$ & $1.80^{d}$ & $1.60^{d}$ & $0.20^{d}$ & $0.18^{d}$ & $0.17^{d}$ & $0.15^{d}$ \\
\hline Decrement \% & & 17.86 & 35.71 & 42.85 & & 10.00 & 15.00 & 25.00 \\
\hline Formula 2 & $95.08^{c}$ & $70.10^{c}$ & $50.30^{c}$ & $40.28^{c}$ & $60.80^{\mathrm{c}}$ & $54.30^{\mathrm{c}}$ & $40.16^{c}$ & $33.70^{\mathrm{c}}$ \\
\hline Decrement \% & & 25.47 & 47.10 & 57.63 & & 10.96 & 33.95 & $44 . .57$ \\
\hline Formula 3 & $189.20^{b}$ & $150.30^{b}$ & $120.24^{b}$ & $100.40^{b}$ & $121.20^{b}$ & $109.16^{b}$ & $89.28^{b}$ & $77.24^{b}$ \\
\hline Decrement \% & & 20.56 & 36.45 & 46.39 & & 9.93 & 26.33 & 36.27 \\
\hline Formula 4 & $278.40^{\mathrm{a}}$ & $220.60^{a}$ & $200.16^{a}$ & $175.80^{a}$ & $180.60^{\mathrm{a}}$ & $167.20^{\mathrm{a}}$ & $140.32^{\mathrm{a}}$ & $126.40^{\mathrm{a}}$ \\
\hline Decrement \% & & 20.76 & 28.10 & 36.85 & & 7.42 & 22.30 & 30.01 \\
\hline
\end{tabular}

Values with different letters in the same column are significant different at $P<.0 .05$.

Formula (1) permeate+ bifidobacteria $\quad$ Formula (2) permeate+ bifidobacteria $+2 \%$ rosella

Formula (3) permeate + bifidobacteria $+4 \%$ rosella Formula (4) permeate + bifidobacteria $+6 \%$ rosella 
Table.4 Anthocyanin and Tannins Contents $(\mathrm{Mg} / 100 \mathrm{ml})$ in Different Formulas during Cold Storage Periods after 21 Days at $\left(4 \pm 1^{\circ} \mathrm{C}\right)$

\begin{tabular}{|c|c|c|c|c|c|c|c|c|}
\hline \multirow[t]{2}{*}{ Treatments } & \multicolumn{4}{|c|}{ Anthocyanin } & \multicolumn{4}{|c|}{ Tannins } \\
\hline & O time & 7 days & 14 days & 21 days & o time & 7 days & 14 days & 21 days \\
\hline $\begin{array}{l}\text { Rosella } \\
\text { calyxes }\end{array}$ & \multicolumn{4}{|c|}{$8.20 \mathrm{mg} / \mathrm{g}$ dry weight } & \multicolumn{4}{|c|}{$0.80 \mathrm{mg} / \mathrm{g}$ dry weight } \\
\hline Formula 1 & \multicolumn{4}{|c|}{$\mathbf{0 . 0}$} & \multicolumn{4}{|c|}{$\mathbf{0 . 0}$} \\
\hline Formula 2 & $15.14^{\mathrm{c}}$ & $14.23^{\mathrm{c}}$ & $13.65^{\mathrm{c}}$ & $12.59^{c}$ & $1.48^{\mathrm{c}}$ & $1.40^{\mathrm{c}}$ & $1.32^{\mathrm{c}}$ & $1.30^{\mathrm{c}}$ \\
\hline Formula 3 & $30.30^{b}$ & $28.33^{b}$ & $26.30^{b}$ & $25.48^{b}$ & $2.60^{b}$ & $2.55^{b}$ & $2.50^{b}$ & $2.44^{b}$ \\
\hline Formula 4 & $46.73^{a}$ & $45.70^{a}$ & $43.45^{a}$ & $42.26^{a}$ & $4.80^{\mathrm{a}}$ & $4.73^{a}$ & $4.68^{a}$ & $4.62^{a}$ \\
\hline
\end{tabular}

Table.5 Iron and Zinc in Different Formulas $(\mathrm{mg} / 100 \mathrm{ml})$ during Cold Storage Periods after 21 days at $\left(4 \pm 1^{\circ} \mathrm{C}\right)$

\begin{tabular}{|c|c|c|c|c|c|c|c|c|}
\hline \multirow{2}{*}{ Treatments } & \multicolumn{4}{|c|}{$\mathbf{F e}$} & \multicolumn{4}{|c|}{$\mathbf{Z n}$} \\
\hline & 0 time & 7 days & 14 days & 21 days & 0 time & 7 days & 14 days & 21 days \\
\hline $\begin{array}{l}\text { Rosella } \\
\text { calyxes }\end{array}$ & \multicolumn{4}{|c|}{$0.37 \mathrm{mg} / \mathrm{g}$ dry weight } & \multicolumn{4}{|c|}{0.0 3mg/ g dry weight } \\
\hline Formula 1 & $0.12^{d}$ & $0.12^{d}$ & $0.11^{d}$ & $0.10^{d}$ & $0.06^{d}$ & $0.06^{d}$ & $0.06^{\mathrm{d}}$ & $0.06^{d}$ \\
\hline Formula 2 & $0.76^{c}$ & $0.75^{c}$ & $0.74^{\mathrm{c}}$ & $0.74^{c}$ & $0.18^{c}$ & $0.18^{c}$ & $0.18^{\mathrm{c}}$ & $0.17^{\mathrm{c}}$ \\
\hline Formula 3 & $1.42^{b}$ & $1.42^{b}$ & $1.41^{b}$ & $1.40^{b}$ & $0.28^{b}$ & $0.28^{b}$ & $0.28^{b}$ & $0.27^{b}$ \\
\hline Formula 4 & $2.21^{\mathrm{a}}$ & $2.20^{\mathrm{a}}$ & $2.20^{\mathrm{a}}$ & $2.19^{a}$ & $0.40^{\mathrm{a}}$ & $0.40^{\mathrm{a}}$ & $0.39^{a}$ & $0.39^{a}$ \\
\hline
\end{tabular}

Values with different letters in the same column are significant different at $\boldsymbol{P}<.0 .05$ Formula (1) permeate+ bifidobacteria Formula (2) permeate + bifidobacteria $+2 \%$ rosella Formula (3) permeate+ bifidobacteria $+4 \%$ rosella Formula (4) permeate + bifidobacteria $+6 \%$ rosella

Table.6 Bifidobacterial Counts (log cfu/g) for Formulas during Cold Storage Periods after 21 days at $\left(4 \pm 1^{\circ} \mathrm{C}\right)$

\begin{tabular}{|c|c|c|c|c|c|}
\hline \multirow[t]{2}{*}{ Microorganisms } & \multirow[t]{2}{*}{ Treatments } & \multicolumn{4}{|c|}{ Period storage } \\
\hline & & 0-time & 7 days & 14 days & 21 days \\
\hline \multirow{4}{*}{$\begin{array}{c}\text { Bifidobacterial } \\
\text { count (log cfu/g) }\end{array}$} & Formula 1 & $8.97^{\mathrm{a}}$ & $8.86^{a}$ & $8.74^{\mathrm{a}}$ & $8.32^{\mathrm{a}}$ \\
\hline & Formula 2 & $8.94^{b}$ & $8.31^{b}$ & $8.02^{b}$ & $7.78^{b}$ \\
\hline & Formula 3 & $8.94^{b}$ & $8.11^{c}$ & $7.75^{\mathrm{c}}$ & $7.24^{c}$ \\
\hline & Formula 4 & $8.91^{d}$ & $7.41^{d}$ & $7.12^{d}$ & $7.06^{d}$ \\
\hline
\end{tabular}

Values with different letters in the same column are significant different at $P<.0 .05$. Formula (1) permeate+ bifidobacteria Formula (2) permeate+ bifidobacteria $+2 \%$ rosella Formula (3) permeate + bifidobacteria $+4 \%$ rosella Formula (4) permeate + bifidobacteria $+6 \%$ rosella $\mathrm{CFU}=$ Colony for Unit 
Table.7 Sensory Evaluation of Different Formulas during Cold Storage at $4 \pm 1^{\circ} \mathrm{C}$ For 21 Days

\begin{tabular}{|c|c|c|c|c|}
\hline Treatment & $\begin{array}{l}\text { Colour } \\
\text { (10) }\end{array}$ & $\begin{array}{l}\text { Taste } \\
\text { (10) }\end{array}$ & $\begin{array}{l}\text { Flavour } \\
\text { (10) }\end{array}$ & $\begin{array}{c}\text { Over acceptability } \\
(\mathbf{3 0})\end{array}$ \\
\hline \multicolumn{5}{|c|}{ Zero Time } \\
\hline Formula 1 & $4^{c}$ & $3^{a}$ & $4^{b}$ & $11^{d}$ \\
\hline Formula 2 & $6^{d}$ & $6^{d}$ & $7^{\mathrm{c}}$ & $19^{b}$ \\
\hline Formula 3 & $10^{b}$ & $9^{c}$ & $10^{\mathrm{a}}$ & $29^{a}$ \\
\hline Formula 4 & $10^{b}$ & $8^{c}$ & $7^{\mathrm{c}}$ & $25^{\mathrm{a}}$ \\
\hline \multicolumn{5}{|c|}{ After 21 days } \\
\hline Formula 1 & $4^{a}$ & $2^{\mathrm{d}}$ & $3^{c}$ & $9^{b}$ \\
\hline Formula 2 & $6^{d}$ & $6^{b}$ & $6^{a}$ & $18^{\mathrm{c}}$ \\
\hline Formula 3 & $10^{\mathrm{c}}$ & $8^{a}$ & $10^{b}$ & $28^{a}$ \\
\hline Formula 4 & $10^{\mathrm{c}}$ & $6^{b}$ & $7^{a}$ & $23^{d}$ \\
\hline
\end{tabular}

Values with different letters in the same column are significant different at $P<.0 .05$.

Formula (1) permeate+ bifidobacteria $\quad$ Formula (2) permeate+ bifidobacteria $+2 \%$ rosella

Formula (3) permeate + bifidobacteria $+4 \%$ rosella $\quad$ Formula (4) permeate + bifidobacteria $+6 \%$ rosella

\section{Microbial Count}

The effect of added 2.0, 4.0 and $6.0 \%$ rosella calyxes on Bifidobacterial counts (cfu/g) for permeate beverages during cold storage periods at $4{ }^{\circ} \mathrm{C}$ are illustrated in Table (6). The change of the viable counts of bifidobacteria during storage period is represented in the same table. Data clearly indicated that the viability of bifidobacteria remained high for 14 days then started to decline. Concerning the therapeutic benefits the product should contain at least $10^{6}$ viable cell of bifidobacteria per gram to realize its therapeutic properties (Lee et al., 1996; and Salem and El-Shirbiny, 2003). As can be seen in the same table probiotic beverage fortified with rosella showed this count remained more suitable during storage till 21 days. The stability of bifidobacterium bifidum counts during storage may be due to the use of antioxidants by bifidobacteria to defiance the degradation of useful bacterial counts.

As result of high hygienic conditions during process and storage, Mould and Yeast counts, Coliform bacterial count and spore forms count were not detected in all treatment when fresh during storage period for permeate beverage.

\section{Sensory Evaluation}

Sensory evaluation of permeate beverages prepared with 2.0, 4.0 and $6.0 \%$ dried rosella calyxes during cold storage period are shown in Table (7). The rosella permeate beverages prepared with $4.0 \%$ rosella (formula 3) gained the highest score for color, appearance and flavor at zero time of storage and after 21 days of storage at $4^{\circ} \mathrm{C} \pm$ $1^{\circ} \mathrm{C}$. Therefore, these samples came in the first order on comparison with other prepared beverages up to 21 days of storage. This treatment was the most acceptable formula followed with permeate beverages prepared with $6.0 \%$ dried rosella (formula 4) and permeate beverages prepared with $2.0 \%$ dried rosella (formula 2) while permeate beverages prepared without dried rosella (formula 1) were unacceptable blends since they had been given the lowest scores.

\section{References}

A.O.A.C. (2000).Official Methods of Analysis of the Association of 
Analytical Chemists.17thed., edited by Horwitz, A.O.A.C., Washington, DC. anthocyanin composition and antioxidant activity of three verities of sorrel (Hibiscus sabdariffa) during maturity. J. of Food Composition and Analysis 22: 663667.

Abd El-Khair, A. A. (2009). Formulation of milk permeates for utilization as electrolyte beverages. Australian J. Basic and App. Sci. 3: 572-578.

Abd El-Salam, M. H.; Mahran, G. A.; Haggag, H. F; Mahfouz, M. B. and Zaglol, A. (1991). Manufacture and properties of beverages based on fermented permeate and natural fruit juices. Chem. Mikrobiol. Technol. Lebensm. 13:95-101

Adenipeku, I. T. (1998). Extraction and colours of Roselle (Hibiscus sabdariffa) juice. M. Sci. Thesis, University of Ibadan, Ibadan.

Ameh, A. O.; Isa, M. T.; Ahmed, A. S and Adamu, S. B. (2009). Studies on the use of trona in improving the taste of the extract from Hibiscus sabdariffa calyx. Nigeria J. of Pharmaceutical Sci., 8 (1): 7-12.

American Public Health Association, A.P.H.A (1994).Standard method of the examination of dairy products 16th Ed., Washington, USA.

Asolkar, L. V.; Kakkar, K. K and Chakre, O. J. (1992). Second Supplements to Chopr,s Glossary of Indian Medicinal Plants with Active Principles Part 1 (A-K). Council of Scientific and Industrial Research, New Delhi, India, ISBN: 8172360487, pp: 44.

Aurelio, D.; Edgardo, R.G and Galindo, S. (2007). Thermal kinetic degradation of anthocyanins in a roselle (Hibiscus sabdariffa L. cv. 'Criollo') infusion (Online).
Available http:// www.blackwellsynergy.com/doi /pdf / 10.1111 /j.1365-2621.2006.01439.x

Beitane, I. (2008). The evaluation of lactulose and inulin for the development of a new functional milk product. Doctoral dissertation, Latvia University of Agriculture, Jelgava, Latvia. 124 pp.

Beitane, I., and Ciprovica, I. (2011). The study of added prebiotics on B group vitamins concentration during milk fermentation. AC Romanian Biotechnol.Lett., 16 (6) Supplement, 92-96.

Bosscher, D.; Breynaert ,A; Pieters,A. and Hermans, N. (2009). Food-based strategies to modulate the composition of the intestinal microbiota and their associated health effects. J. Physiol. And Pharmacol., 60(6): 5-11.

Crittenden, R. G., Martinez, N. R.andPlayne, M. J. (2003). Synthesis and utilization of folate by yoghurt starter cultures and probiotic bacteria. Int. J. Food Microbiol., 80, 217-222.

Dave, R.I. and Shah, N.P.(1996). Evaluation of media for selective of media of Streptococcus thermophillus, Lactobacillus debrukii spp., Bulgaricus; Lactobacillus acidophilus and Bifidiobacteria. J. Dairy Sci., 79:1529-1533.

Dong, P., Yang, Y., and Wang, W.-P. (2010). The role of intestinal bifidobacteria on immune system development in young rats. Early Hum.Devel., 86,51-58.

Du, C. T and Francis, F. J. (1973). Anthocyanins of Roselle (Hibiscus sabdariffa L.) J. Food Sci., 38: 810812.

El-Saidy, S. M.; Ismail, I.A and EL-Zoghbi, M. (1992). A study on Roselle extraction as a beverage or as a source for anthocyanins. Zagazig J. 
Agric. Res., 19: 831-839.

Fasoyiro, S.B. ;Babalola, S.O. and Owosibo, T.(2005). Chemical Composition and Sensory Quality of Fruit-Flavoured Roselle (Hibiscus sabdariffa) Drinks. World Journal of Agricultural Sciences 1 (2): 161-164.

Harrigan, W.F. and MaCance,M.E.(1996). Laboratory Methods in microbiology. Academic poress, London\& New York,292-293.

He, T., Priebe, M.G., Zhong, Y., Huang, C., Harmsen, H. J. M., Raangs, G.C., Antoine, J. M., Welling, G. W. and Vonk, R. J. (2007). Effects of yogurt and bifidobacteria supplementation on the colonicmicrobiota in lactoseintolerant subjects. J. Appl. Microbiol., 104, 595-604.

Hiai, S.; Qura, H., and Nakajima, T.(1976). Color reaction of some sapongenins and saponin with vanillin and sulfuric acid.PlantaMedica, 29, 116122.

Hughes, D.B. and Hoover, D.G. (1991).Bifidobacteria: Their potential for use in American dairy products. Food technol., 45: 74-83.

Jeon, I.J.; Galitzer S.J., and Hennessy K.J., (1984). Rapid determination of lactose and its hydrolyzates in whey permeate by high performance liquid chromatography. J. Dairy Sci., 67: 884-887.

Kroon, A.P.; Clifford, N.M.and Crozier, A. (2004). How should we assess the effects of exposure to dietary polyphenols in vitro?. Am. J. Clin. Nutr., 80: 15-21.

Lee, J.H.; Shin, H.S.; Pestaka, J.J. and Ustunal , Z.(1996). Effect of oligosaccharides and inulin on growth and viability of bifidobacteria in fermented milk. J. Dairy Sci. suppl. 1: 79-124.

Ling, E.R.(1963). A text book of dairy chemistry .Vol. 11,3rd Ed., Chapman and Hall, Ltd. London.

Manach, C.; Scalbert,A.; Morand,C. Remesy ,C. and Jimenez, L. (2004). Polyphenols: food sources and bioavailability. Am. J. Clin. Nutr., 79: 727-747.

Marhamatizadeh,

M.H.;

Rezazadeh,F.;Kazemeini.H.

andKazemi, .M. R.. (2012). The Study of Probiotic Juice Product Conditions

Supplemented by Culture of Lactobacillus acidophilus and Bifidobacteriumbifidum. Middle-East Journal of Scientific Research 11 (3): 287-295.

Marshall, T.R. (1993). Standard methods for the examination of dairy products 16th ed., Amer. Publ. Health Assoc. Inc. Washington, D.C.

Nuzhat, A.; Huma K. H. and Ahmed, L. (2003). Preparation and evaluation of apple stirred yoghurt. Pak. J. Food Sci., 13:5-9.

Oliveira, R. P. D. S., Florence, A. C. R., Perego, P., De Oliveira, M. N. and Converti, A. (2011). Use of lactulose as prebiotic and its influence on the growth, acidification profile and viable counts of different probiotics in fermented skim milk. Int. J. Food Microbiol., 145, 22-27.

Parvez, S., Malik, K. A., Ah Kang, S. and Kim, H.-Y. (2006). Probiotics and their fermented food products are beneficial for health. J. Appl. Microbiol., 100, 1171-1185.

Pharmacopeia (1989). The state Pharmacopeia of USSR, Moscow, 2: 324-334. (C.F., Food Chem., 85: 231237, 2004).

Prenesti, E.; Berto, S.; Daniele, P. G andToso, S. (2007). Antioxidant power quantification of decoction and cold infusions of Hibiscus sabdariffa flowers. Food Chemistry 
100: 433-438.

Qiao, H., Duffy, L. C., Griffiths, E., Dryja, D., Leavens, A., Rossman, J. O.N., Rich, G., Riepenhoff-Talty, M. and Locniskar, M. (2002). Immune responses in rhesus rotaviruschallenged BALB/c mice treated with bifidobacteria and prebiotic supplements. Pediatric Res., 51, 750755.

Ranganna, S. (1979).Manual of Analysis Fruit and Vegetable Products. Tata, M. Graw Hill, publishing company limited, New Delhi, PP. 150-161.

Rastall, R. A. and Maitin, V. (2002). Prebiotics and synbiotics: Towards the next generation. Curr. Opinion Biotechnol., 13, 490-496.

Renner, J. E. and Abd El-Salam, M. H. (1991). Application of Ultrafiltration in the Dairy Industry. Elsevier App. Sci., London and New York.

Russell, D. A., Ross, R. P., Fitzgerald, G. F. and Stanton, C. (2011).Metabolic activities and probiotic potential of bifidobacteria. Int. J. Food Microbiol., 149, 88-105.

Salem, Aida S. and El-Shribiny, Safinaz (2003).Probiotic , prebiotic and symbiotic and their potential application in functional dairy foods (A Review). Egyptian J. Dairy Sci., 31: 195-219.

Singleton, V.L. and J.A., Rossi (1965).Colorimetry of total phenol with

phosphomolybdicphosphotungstic

acid reagents. Amer. J. Enol. and Viticulture, 16:144 - 158.

SPSS (2011).SPSS for Windows.Release 10 (October 2011) Standard Version.

Tsai, P.J.; McIntosh, J.; Pearce, P.; Camden, B and Jordan, R.B. (2002). Anthocyanin and antioxidant capacity in Roselle (Hibiscus sabdariifa L.) extract. J. Food ResInt, 35, 351-
356.

Tzu-Lilin; Lin, H.H.; Chen, C.C.; Lin, M.C.; Chou, M.C and Wang, C.J. (2007). Hibiscus Sabdariffa extract reduces serum cholesterol in men and women. Nutrition Research 27: 140145.

Ziarno, M., Sekul, E. and Lafraya, A. A. (2007).Cholesterol assimilation by commercial yoghurt starter cultures.ActaScientiarumPolonorumT echnologiaAlimentaria, 6, 83-94. 